\title{
The Economic study of producing Spirulina Algae in Egypt
}

\author{
Abeer Farouk Mahmoud Abdel-Rehim Tammam \\ Modern Academy for Computer Science \\ and Management Technology in Maadi
}

\begin{abstract}
Algal production is a promising and an important field of research because of its healthy and environmental advantages as the main problem is that there is an increase in the prices of oil and natural gas and there is a need to find other alternatives, accordingly the best solution is producing Spirulina algae.

The high and rapid growth rates, high oil contents and high nutritional values, high per acre yield and ability to reduce the greenhouse gas concentration in the atmosphere, easy and cheap to produce locally. Spirulina has the potential to produce both food and biofuel far more rapidly and efficiently, and with a much smaller environmental footprint than conventional crops, also sustainable solution to the problem of malnutrition.

This paper focuses on the economic study of producing spirulina algae and its potential production and uses in Egypt.
\end{abstract}

Key words: Algae, Biofuels, Economic study, Spirulina algae. 


\section{Introduction}

Spirulina is a Super food, it is an edible microlage, classified as blue - green algae, and its scientific name is Arthrospira Plantensis. Since its re-discovery in the 1960s, spirulina has been exhaustively and extensively tested by scientists around the world, and is found to be the most powerful and well-balanced source of nutrition available on the planet. ${ }^{1}$

It is naturally found and consumed as a safe food by millions of people in the alkaline lakes of Mexico, Asia, Europe and Africa, Furthermore, many governments, health agencies and associations of over 70 countries have approved Spirulina as a food for human consumption.

Spirulina can be grown successfully in ponds by recreating its natural environment of high $\mathrm{pH}$, alkaline and saline water; it can also be harvested and used as a supplement for growing fish and aquatic organisms within an integrated aquaponics system. ${ }^{2}$

Spirulina contains about $70 \%$ protein content, along with high amounts of essential fatty acids, essential amino acids which are easily digestible especially people with poor digestive systems. Spirulina is also sispephigh in minerals, iron, vitamins (especially B12), and chlorophyll. Consequently, the commercial production of Spirulina has gained worldwide attention for use in human food supplements, animal feed and pharmaceuticals.

The small-scale production of spirulina is considered as a potential income-generating activity for households or village collectives. Spirulina might be also dried and processed for local consumption, especially where poor dietary regimes need to be supplemented. In addition, the extensive or semi intensive

${ }^{1}$ http://www.auroville.org/contents/114

${ }^{2} \mathrm{M}$. Ahsan B. Habib... [and others], A review on culture, production and use of Spirulina as food for humans and feeds for domestic animals and fish, Rome, Italy :FAO, 2008. 
production of spirulina for animal or aquatic feeds might be conducted for small-scale farming and aquaculture. ${ }^{3}$

\section{Problem of the Study:}

Obtaining a clean energy has become a major concern for many countries of the world, as many of the nations is suffering from economical and environmental problems due to the current global oil production is approaching its peak, along with billions of tons of carbon emissions released into the atmosphere leading to global warming, threats of climatic change coupled with great obstacles to further development of conventional energy sources, it is very important that a great attention will be given to a range of environment-friendly renewable energy resources which are expected to play an important role in averting an impending future energy crisis (Kifayat Ullah and others, $2004)^{4}$.

Egypt is suffering from an annually increasing demand on Energy sources as a result of the expansion of economic activities and development projects which will generate a deficit of energy in the coming years, so all these problems led the world specially Egypt to shed light on a new alternatives and renewable energy from raw materials which don't affect the health of human and animal production in what has become known as the third biofuels generation.

An increasing number of developed and rapidly developing nations see biofuels as a key to reducing reliance on foreign oil, lowering emissions of greenhouse gases (GHG), mainly carbon

\footnotetext{
${ }^{3}$ FAO (2008), Fisheries and Aquaculture Circular No. 1034, a review on culture, production and use of Spirulina as food for humans and feeds for domestic animals and Fish, Rome, P.10 ${ }^{4}$ Kifayat Ullah and others (2014), Algal biomass as a global source of transport fuels: Overview and development perspectives, Elsevier, (2014)329-339.
} 
dioxide $\left(\mathrm{CO}_{2}\right)$ and methane $\left(\mathrm{CH}_{4}\right)$, and meeting rural development goals (A. Milbrandt, C. Kinchin, 2013) .

\section{The Hypothesis of the study:}

Spirulina algae is a nascent technology at commercial scale, so the replacement of it as the third generation fuel, and as an alternative source of new and renewable energy will solve in many of the environmental pollution as well as the problem of food gap and increasing prices of petroleum.

\section{The objectives of the study:}

The research seeks to clarify the benefits resulting from using spiraling algae as it can be produced in the desert land and the saline water, the algae can turn the Egyptian economy to an integrated economy contributes to the prosperity of the society. On the short run it will have social impact by providing job opportunities for large numbers of youth in the deserts, where Egypt has vast expanses of deserts represent $96 \%$ of the area of Egypt. Also it owns 8,200 $\mathrm{km}$ beaches overlooking the Mediterranean Sea and the red sea therefore, all the desert locations adjacent to these beaches can set up projects for the production of spirulina algae. Hence algae will contribute to the purification of water and air pollution and harmful emissions.

\section{Methodology of the study:}

The methodology of the study is the analytical method, through the analysis of the economics of the data, information from various sources that are related to the research, analyzing the problem of the research and its dimensions through using different references related to the subject of the study.

\footnotetext{
${ }^{5}$ Giuliano Dragone, Bruno Fernandes (2010) Third generation biofuels from microalgae, http://www.formatex.info/microbiology2/1355-1366.pdf
} 


\section{Study Plan:}

Chapter one: The Economic importance and technical specifications of Spirulina algae

Chapter two: The Marketing, Environmental and Economic study of cultivating Spirulina algae

\section{Chapter one: The Economic importance and technical specifications of Spirulina algae}

First: Introduction to Spirulina Algae

Spirulina algae is known as a super food; it is marketed throughout the world as a food supplement for people of all ages and lifestyles. It is considered as an important food full of nutritional components.

Spirulina's concentrated nutrition makes it an ideal food supplement for people of all ages and lifestyles (Bob Capelli, Gerald R. Cysewski, 2010) ${ }^{6}$.

In the 1960s Spirulina was discovered to be an ordinary food for the people who were living around the alkaline Lake Chad in Africa, the first commercial spirulina production plant was in operation at a large bicarbonate evaporation basin near Mexico City by the early 1970s (although it closed in 1995 for reasons unrelated to its algae production business) (T.J. Lundquist, L.C. Woertz, October 2010) ${ }^{7}$.

Spirulina is microscopic plant with a nuclear structure but no membrance, belonging to the prokaryote group of blue-green algae known as Cyanophyceae. It is very high in protein, very low in calories and cholesterol, and high in enzymes, minerals

\footnotetext{
${ }^{6}$ Bob Capelli, Gerald r. Cysewski (2010), Potential health benefits of Spirulina microalgae: A review of the existing literature, Research Nutrafoods, Volume9, Issue 2, pp 19-26 available online at www.ceceditore.com

${ }^{7}$ T.J. Lundquist, L.C. Woertz, (October 2010), A Realistic Technology and Engineering Assessment of Algae biofuel Production, energy Biosciences Institute University of California, Berkeley, California.
} 
(iron, calcium, sodium and magnesium), and phenolic acids, which have antioxidant properties (Anitha Layam, Chandra Lekha Kasi Reddy, 2007) ${ }^{8}$.

Spirulina algae is multicellular and filamentous blue-green microalgae belonging to two separate genera Spirulina and Arthrospira and consist of about 15 species (FAO, 2008) ${ }^{9}$.

Spirulina is now on the following forms: baked desserts, beer, breakfast cereals, confectionary, corn chips, crackers, doughnuts, food bars, frozen desserts, juice smoothies, muffins, pasta, popcorn, salad dressing, snack foods, and soups.

Spirulina in the form of tablets and capsules is widely marketed as a dietary supplement, with an extremely wide range of alleged medical and health benefits.

Spirulina didn't come into commercial production until the 1970s, when a French company began the first large-scale spirulina production plant. Within a few years, America and Japan began producing their own spirulina.

Spirulina grows naturally in alkaline lakes, and has a long history of being used as a human food. It is a type of algae growing in Equatorial Lakes saltwater, where discovered by Dr. Clemente in France in 1962, it also recognized by the World Health Body and the United Nations on behalf of the food supermarkets and best food for the future.

Spirulina species have the potential to produce both food and biofuel far more rapidly and efficiently, and with a much smaller

\footnotetext{
${ }^{8}$ Anitha Layam, Chandra Lekha Kasi Reddy (2007), ANTIDIABETIC PROPERTY OF SPIRULINA, Department of Food Science and Nutrition, SPMVV, Tirupati, India.

9 FAO (2008), Fisheries and Aquaculture Circular No. 1034, a review on culture, production and use of Spirulina as food for humans and feeds for domestic animals and Fish, Rome.
} 
environmental footprint, than conventional crops (Ernest Small, 2012) ${ }^{10}$.

Spirulina has been fed extensively to malnourished children, and has proven to be an excellent supplement for restoring them to nutritional health. Spirulina can be able to play a significant role as a way to fight malnutrition in developing countries.

Algae also produce proteins that could be used as a source of animal feed, and some pharmaceuticals (Raphael Slade, Ausilio Bauen, 2013) ${ }^{11}$.

\section{Second: Spirulina Production Process}

The commercial producers of Spirulina are located in the United States, Taiwam, India, China, Thailand, Japan, Israel, Pakistan, Burma and Chile.

\section{1- Cultivation:}

Most cultivated spirulina is carried out in open-channel raceway ponds, with paddle-wheels used to actuate the water.

Two types of open raceway ponds are typically used: the first is lined by concrete and is therefore expensive, the second is a shallow earthen tunnel lined with polyvinyl-chloride (PVC) or some other durable plastic material.

Commonly used open systems include raceways, open ponds, or channels. Raceway ponds are the most commercially used of the open systems, and are typically placed outside to make use

\footnotetext{
10 Ernest Small (2012): 37. Spirulina: food for the universe, Biodiversity, available online at http://dx.doi.org/10.1080/14888386.2011.642735

${ }^{11}$ Raphael Slade, Ausilio Bauen, (2013) Micro-algae cultivation for biofuels: cost, energy balance, environmental impacts and future prospects, Elsevier Ltd.

12 FAO (2008), Fisheries and Aquaculture Circular No. 1034, a review on culture, production and use of Spirulina as food for humans and feeds for domestic animals and Fish, Rome, P.13.
} 
of natural illumination ${ }^{13}$. Raceway ponds do not produce optimal productivities but are favored because they are relatively simple and are low- $\operatorname{cost}^{14}$. Photobioreactors are a closed system for algae cultivation. To date, algal growth in open pond systems has been able to produce 0.06-0.231 g/l/day of biomass and nearly $3 \mathrm{~g} / \mathrm{l} /$ day in bioreactors ${ }^{15}$.

Spirulina Cultivation has the following advantages:

- It uses less water per kilo of protein than other crops, and it doesn't require fertile land and saline water can be utilized.

- It contains more than $70 \%$ protein, and it has a rapid growth as it yields 20 times more protein per unit area than soybeans, 40 times more than corn, and over 200 times more than beef.

\section{2- Harvesting:}

As Spirulina grows in strands, it's shape allows it to be harvested by stainless steel screens, and to ensure that Spirulina is cleaned with a fresh taste, it is given several fresh water washes. The best time for harvesting is the early mornings so that the sunshine hours will be available for drying, the percentage proteins in Spirulina is high in the morning and the cool temperature makes the work more easily.

The main steps in the harvesting are as follow: ${ }^{16}$

\footnotetext{
${ }^{13}$ Pokoo-Aikins, Grace, Ahmed Nadim, Mahmoud m. El-Halwagi, and Vladimir Mahalec (2010), "Design and analysis of biodiesel production from algae grown through carbon sequestration." Clean Technologies and Environmental Policy, P44.

${ }^{14}$ Sheehan, J.; Dunahay, T.; Benemann, J.; Roessler, P. A (1998) Look Back at the U S Department of Energy's Auatic Species Program - Biodiesel from Algae. Vol. 328. National Renewable Energy Laboratory; Co, USA.

${ }^{15}$ Michale Hannon, Javier Gimpel, Miller Tran, Beth Rasala, Stephen Mayfield (2010), Biofuels from algae: challenges and potential, NIH, Biofuels, 1(5):763-784. Available online at http://www.ncbi.nlm.nih.gov/pmc/articles/PMC3152439/

16 FAO (2008), Fisheries and Aquaculture Circular No. 1034, a review on culture, production and use of Spirulina as food for humans and feeds for domestic animals and Fish, Rome.P.17
} 
1- Filtration and cleaning: A nylon filter at the entrance of the water pond is needed to obtain a "biomass" containing about 10 $\%$ dry matter $(1$ liter $=100 \mathrm{~g}$ dry) and $50 \%$ residual culture medium.

2- Removal of the residual culture medium to obtain the "fresh Spirulina Biomass", ready to be consumed or dried, containing about $20 \%$ dry matter and particularly no residual culture medium.

\section{Third: The benefits of Spirulina algae}

Many Countries tried to ease and solve the problem of malnutrition, whether through personal efforts or large-scale mobilization. These efforts have breathed new life into the Millennium Development Goals of the United Nations, the first of which is the destruction of world hunger.

It is the goal of IIMSAM (the Intergovernmental Institution for the use of Micro-Algae Spirulina Against Malnutrition, an Intergovernmental observer to the Economic and Social Council of the United Nations) to be a key driver in the achievement of this goal. IIMSAM recognizes the great potential of Spirulina to feed the hungry masses, as does the United Nations.

In 1974, Spirulina was declared by the United Nations Food Conference as, "the best food for the future". ${ }^{17}$ In 2008, the United Nations Food and Agriculture Organization (FAO) released a report in which they urged governments to reevaluate the potential of Spirulina to fulfill food security needs.

Spirulina, an alga, is the richest whole-food source available in nature. It is extremely digestible and contains every natural known antioxidant a healthy body could need. It is rich in

\footnotetext{
17"What the United Nations says about Spirulina" (PDF). Spirulina and the Millennium Development Goals. Intergovernmental Institution for the use of Micro-algae Spirulina against Malnutrition. December 2010. Cited http://www.iimsam.org/images/SPIRULINAANDTHEMDGsRevisedDEC2010.pdf
} 
vitamins, minerals, carotenoids and perhaps most importantly for those who are malnourished-protein. In fact, with around $70 \%$ protein content, Spirulina yields 20 times more protein per unit area than soybeans, 40 times more than corn, and over 200 times more hat beef. Just one gram of Spirulina a day is sufficient to bring a child who is severely malnourished to health, and this can all be accomplished within a few weeks.

These algae can double its biomass every 2 to 5 days; this productivity breakthrough yields over 20 times more protein than soybeans in the same area, 40 times corn and 400 times beef. Spirulina can flourish in ponds of brackish or alkaline water built on already infertile land. In this way, it can augment the food supply, not by clearing the disappearing rainforests, but by cultivating the expanding deserts.

Table (1)

Chemical Composition for $10 \mathrm{gm}$ dry weight Spirulina

\begin{tabular}{|c|c|}
\hline Content & Amount \\
\hline Proteins & $6.5 \mathrm{~g}$ \\
\hline Beta carotene & $14 \mathrm{mg}$ \\
\hline Vitamin C & $2 \mathrm{mg}$ \\
\hline Thiamin (B1) & $0.37 \mathrm{mg}$ \\
\hline Riboflavin (B2) & $0.46 \mathrm{mg}$ \\
\hline Niacin & $1.3 \mathrm{mg}$ \\
\hline Calcium & $150 \mathrm{~m}$ \\
\hline Iron & $18 \mathrm{mg}$ \\
\hline Vitamin E & $0.4 \mathrm{mg}$ \\
\hline Vitamin B 6 & $0.07 \mathrm{mg}$ \\
\hline Vitamin B 12 & $0.02 \mathrm{mg}$ \\
\hline Phosphorus & $67 \mathrm{mg}$ \\
\hline Magnesium & $32 \mathrm{mg}$ \\
\hline Copper & $0.1 \mathrm{mg}$ \\
\hline Phycocynin & $1500 \mathrm{mg}$ \\
\hline Gamma-Linoleic acid & $100 \mathrm{mg}$ \\
\hline Chiorophyll & $110 \mathrm{mg}$ \\
\hline Source: SODELAC, 2000
\end{tabular}

Source: SODELAC, 2000 
From health perspective Spirulina algae can help in regulating blood sugar, blood pressure and cholesterol; a food that can alleviate pain from inflammation and deliver antioxidant activity to ward off life threatening diseases like cancer, Alzheimer's, heart disease and stroke; a food that helps and protects the liver and kidneys and removes radiation from the body; a food that improves the immune system alleviates allergies and has been proven to fight many different viruses; a food that helps your eyes and brain; a food that can actually help you lose weight, increase friendly flora in the intestines and improve digestion. Spirulina alga contains very essential amino acid; it is rich in B vitamins, minerals, trace elements, chlorophy11, and enzymes.

The previous table shows the chemical composition for 10 gm dry weight Spirulina.

\section{Fourth: Biofuels from Algae}

Algae are a potential aquatic oil crop; this feedstock has received increased attention in recent years. There are around 25,000 species of algae in the world, as for the third generation of biofuels consists of fuel plant cells (algal oil).

Microalgae biofuel offer great potential as it is identified as one of the major renewable energy sources for sustainable feedstock for the production of third generation biofuels, such as biodiesel and bioethanol. Given the right resources-suitable climate, availability of water, $\mathrm{CO}_{2}$ and other nutrients - algal oil productivity can be quite high. (A. Milbrandt, C. Kinchin, 2013) ${ }^{18}$.

The use of Algae for biodiesel production are emerging to be one of the most promising long-term, sustainable sources of biomass and oils for fuel, food, feed, and future technology,

\footnotetext{
${ }^{18}$ A. Milbrandt, C. Kinchin (2013), the Feasibility of Producing and Using Biomass-Based Diesel and Jet Fuel in the United States, NREL/TP-6A20-58015, p.1
} 
algae are a large and diverse group of simple plant-like organisms, ranging from unicellar to multicellar forms. These cells have the ability to convert carbon dioxide to biomass that can further be processed downstream to produce biodiesel, fertilizer and other useful products.

Mostafa, S.S.M., and El-Gendy have clarified that biofuel from algae are promising new source of fuel due to the following advantages:

Minimal land use: Algae require much less land that traditional row crops, such as corn. In addition, algae can grow on nonarable, nutrient-poor land that won't support conventional agriculture. Algae can be cultivated in a wide

- variety of conditions, even in salt water and water from polluted aquifers.

- Algae can grow fast: Algae can double their numbers every few hours, can be harvested daily, and have the potential to produce a volume of biomass and biofuel many times greater than that of our most productive crops.

- Algae can have higher biofuel yield: algae can store energy in the form of oils and carbohydrates, which, combined with their high productivity, also can grow quickly at a large scale and can generate up to 50 times more the amount of oil per acre than row crops, like corn and soybeans, which produce vegetable oil.

- Algae don't compete with agriculture: Production of algae for biofuel doesn't require arable land needed for food production, fresh water for irrigation, or application of petroleum-based fertilizers.

- Algae Consume $\mathrm{CO}_{2}$ : algae use sunlight for growing, consume (or absorb) carbon dioxide $\left(\mathrm{CO}_{2}\right)$ as they grow, release oxygen $\left(\mathrm{O}_{2}\right)$ for the rest of us to breathe. For high productivity, 
algae require more $\mathrm{CO}_{2}$, which can be supplied by emissions sources such as power plants, ethanol facilities, and other sources.

Since the mid 70's microalgae have been extensively researched as a non-food based biodiesel feedstock due to their high oil content, rapid growth rate, high per-acre yield and ability to reduce the greenhouse gas concentration in the atmosphere. Microalgae are generally more efficient in converting solar energy and excessive amounts of $\mathrm{CO}_{2}$ into biomass than land plants; $1 \mathrm{~kg}$ of algal biomass requires about $1.8 \mathrm{~kg}$ of $\mathrm{CO}_{2}$ (Mostafa, S.S.M., El-Gendy, N.S, 2013) ${ }^{19}$.

Algae efficiently use $\mathrm{CO}_{2}$, and are responsible for more than $40 \%$ of the global carbon fixation, with the majority of this productivity coming from marine microalgae. Algae can produce biomass very rapidly, with some species doubling in as few as 6 hours and many exhibiting two doublings per day. All algae have the capacity to produce energy-rich oils, and a number of micro algal species have been found to naturally accumulate high oil levels in total dry biomass (Michael Hannon, Javier Gimpel, 2010) ${ }^{20}$.

\section{Chapter two: The Marketing, Environmental and Economic study of cultivating Spirulina algae}

As a result of economic and social problems which the Egyptian economy is suffering from like the steadily increase of the population, lack of oil supply and inadequate gas for

\footnotetext{
${ }^{19}$ Mostafa, S.S.M., el-Gendy, N.S. (2013), Evaluation of fuel properities for microalgae Spirulina platensis bio-diesel and its belnds with Egyptian petro-diesel Spirulina platensis bio-diesel, Arabian Journal of Chemistry.

${ }^{20}$ Michale Hannon, Javier Gimpel, Miller Tran, Beth Rasala, Stephen Mayfield (2010), Biofuels from algae: challenges and potential, NIH, Biofuels, 1(5):763-784. Available online at

http://www.ncbi.nIm.nih.gov/pmc/articles/PMC3152439/
} 
domestic consumption, Spirulina alga is considered to be as one of the pilot projects to solve these problems. Spirulina alga is the hope of Egypt in the coming years if they best exploited optimally. Spirulina alga is being recognized as a prospective high-yield feedstock for biofuels production, eliminating poverty and on the treatment of many diseases.

\section{First: Environmental Study}

One of the important purposes for producing biofuels from algae is to reduce greenhouse gas emissions into the atmosphere, and also to reduce the effects of global warming produced by fossil fuels, microalgae are preferable for the production of biofuels because they contain more oil, and are easier and faster to grow.

Algae-derived biofuel can reduce life cycle $\mathrm{CO}_{2}$ emissions by $50 \%$ to $70 \%$ compared to petroleum fuels. The productivity of algae is influenced by many environmental conditions, including temperature, light, and wind-blown materials in arid or semi-arid areas that become sediment in open ponds and that constitute ash in the conversion processes (Sayre, R., 2013) ${ }^{21}$.

In order to grow algae, there must be an appropriate environment for growth and there should be minerals and salts available as a food in the water, as well as it is necessary to design the farm so as to include the temperatures of 27 to 30 degrees Celsius and intensity of appropriate lighting and supply of $\mathrm{CO}_{2}$.

A large quantity of waste water is extracted from industries, factories, municipal sewage etc. Municipal waste water contains nutrients approximately 30-100 ppm of nitrogen, 10-45 ppm of phosphorous - which can be utilized for algal cultivation.

\footnotetext{
${ }^{21}$ Sayre, R., (2013) Algal biology and cultivation. Technical Accomplishments, Progress and Results. Presentation at 2013 Bioenergy Technologies Office Peer Review, Alexandria, VA, May 2013. https:www2.eere.energy.gove/biomass/peer_review2013/Portal/IBR./\#.
} 
Algae cultivation requires the provision of large quantities of nutrients, especially nitrogen and phosphorus which presence in the water, to ensure high yield. Algae can remove nitrogen and phosphorus from the wastewater so it can contribute to the purification of water and air pollution and harmful emissions. The project is considered as a new step toward the preservation of the environment, and creation of new jobs to youth.

Environmental factors such as temperature, light, $\mathrm{pH}$, and nutrients, all of these factors can affect photosynthesis and the growth rate of the algae as it can grow much faster than food crops.

Algae can be grown on the reduced need of agriculture land; reduced need for water treatment, also Algae cultivation requires no external subsidies of insecticides or herbicides, algae have the potential to use much less amount of water per kilo than other crops.

Photosynthetic growth of algae requires carbon dioxide, water and sunlight; temperature should be in the range of 20-30 degrees Celsius in order to have good growing conditions.

Algae also need other inorganic nutrients like phosphorus and nitrogen in order to grow. The fact that micro algae grow in aqueous suspensions, allows for more efficient access to $\mathrm{H}_{2} \mathrm{O}$, $\mathrm{CO}_{2}$ and other nutrients which explains the potential for the production of more oil per unit area than other corpus currently used. The chemical composition of algae differs based on species. Algae have several characteristics that cause them to be a candidate biodiesel feedstock that deserves serious investigation (Pokoo-Aikins, Grace, Ahmed Nadim, 2010) ${ }^{22}$.

\footnotetext{
${ }^{22}$ Pokoo-Aikins, Grace, Ahmed Nadim, Mahmoud M. El-Halwagi, and Vladimir Mahalec (2010), "Design and analysis of biodiesel production from algae grown through carbon sequestration. "Clean Technologies and Environmental Policy, P44.
} 
Algae can produce 15-300 times more oil per acre that any of the traditional crops, such as soybeans, rapeseed, oil palms, jatropha, because the entire algal organism can use sunlight to produce lipids or oils. Also Algae can grow on land that is not suitable for other established crops; they can be produced by using sea water as well as wastewater.

Spirulina recycles more than 6.3 tons of $\mathrm{CO}_{2}$ per hectare per

year, on the other hand it produces about 16.8 tons of oxygen. The farming of Spirulina also helps prevent the erosion of soil. Spirulina is the most protein rich food and because of its fast multiplying rate it gives about 20 times more protein per acre than Soya beans, 40 times more than corn and about 200 times more than beef.

Figure 2. A Pilot of Spirulina Farm

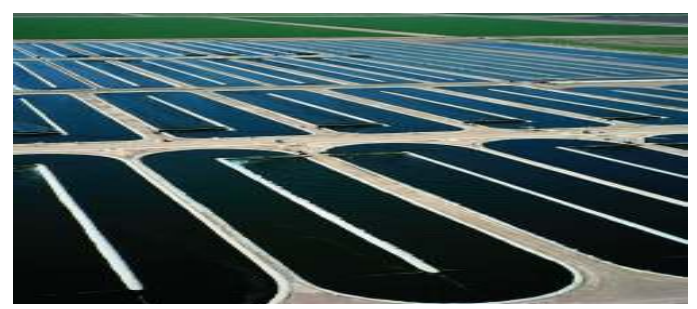

Second: Economic Analysis:

Economic analysis is performed to determine profitability of producing Spirulina as a food, an algal oil and as a medicine. The project can help in solving the unemployment problem which most of the Egyptian youth suffer from by finding new jobs.

Estimated costs of starting ten acres of pilot spirulina farm (All costs in L.E.)

Tables (2) provide a preliminary set of investment costs for 10 pond-acre algae farms; 
1- Components of the Spirulina algae project:

- The land: The Land required for the project is ten acres .The pilot farm should be operated at least ten years to quantify productivity.

- The project consists of five basins (The basin area of each acre $\left(4,200 \mathrm{~m}^{2}\right)$

- Each basin has a boundary wall; its height is $50 \mathrm{~cm}$ and has a special design for breeding algae.

- The project needs two trusses; the height of the first one 6 meters by $150 \mathrm{~cm}$ high walls, and an area of $500 \mathrm{~m}^{2}$ and the second one with an area of $200 \mathrm{~m}^{2}$ with $150 \mathrm{~cm}$ high wall

- Office building with an area of $300 \mathrm{~m}^{2}$.

- Residential building for employment with an area of $300 \mathrm{~m} 2$

- Store with an area of $100 \mathrm{~m}^{2}$

- We utilize the first basin (about one acre) in the production of spirulina, and the other four pools (each basin area of $4200 \mathrm{~m}^{2}$ ) in the cultivation of other algae for the production of biofuel.

- All basins are provided with Ventilation working to turn the water in the pond, and all the basins are provided with filters to collect the algae every 8 hours.

- Electricity is supplied through wind energy and photovoltaic cells to run harvesting/extraction equipment, paddlewheels and pumps.

2- Revenues:

First: The revenues from the first Basin (with an area of $\underline{\left.4200 \mathrm{~m}^{2}\right)}$

- It is for the cultivation of Spirulina algae, it is collected every eight hours daily through filters specialized in collecting aglae.

- The basin is one acre and it gives daily from $10 \mathrm{~kg}$ to $20 \mathrm{~kg}$ of algae according to the duration that the basin was exposed to the sun and the length of the day. 
- Daily production / 10000 gm

- The price of one gram sold is one Egyptian Pound.

- The daily yield from the first basin (Spirulina) is 10.000 L.E. (1)

Second: The Revenue from the four Basins (Each basin has an area of $4200 \mathrm{~m}^{2}$ )

- We will plant an algae that product biofuels such as algaeoleum, one acre gives daily from $100 \mathrm{~kg}$ to $200 \mathrm{~kg}$ of this algae and after the compress of these algae they give the following:

1. $60 \%$ of production pure biodiesel and glycerin oil.

2. $40 \%$ of the production animal feed.

- Daily production for the one basin:

$\Rightarrow 60 \%$ of the production Biodiesel (Biofuel) and

\section{Glycerin}

$60 \% * 100 \mathrm{~kg}=60 \mathrm{~kg}$ (oil)

After treatment and purification:

- $54 \%$ pure Biofuel

- $6 \%$ Glycerin

$\Rightarrow \underline{40 \%}$ of the production animal feed and Fodder Concentrates

$$
40 * 100 \mathrm{~kg}=40 \mathrm{~kg} \text { (oil) }
$$

- Daily production for the four basins:

1 - Pure Biofuel: $\quad 54 \mathrm{~kg} * 4$ basins $=216 \mathrm{~kg}$

The value of one $\mathrm{kg}$ of biofuel $=1.5 \$$

$$
\begin{array}{ll}
216 \mathrm{~kg} * 1.5 \$ & =324 \$ \\
324 \$ * 8 \mathrm{~L} . \mathrm{E} . & =2592 \mathrm{~L} . \mathrm{E} .
\end{array}
$$

2 - Pure Glycerin: $\quad 6 \mathrm{~kg}$

It gives us $(6 \mathrm{~kg} * 4$ basins $)=24 \mathrm{~kg}$ Glycerin

$24 \mathrm{~kg} * 8.5 \$$ price for glycerin

$$
\begin{aligned}
& =204 \$ \\
& =1632 \text { L.E. }
\end{aligned}
$$$$
204 \$ 8 \text { L.E. }
$$ 
3 - Animal feed:

The value of one kilogram of feed $=60$ L.E.

$\therefore$ Total revenue from animal feed $=40 \mathrm{~kg} * 4$ basins

$$
=160 \mathrm{~kg}
$$

\section{$\therefore$ Total Revenue from four basins}

$$
160 \mathrm{~kg} * 60 \text { L.E. }
$$

$$
\begin{aligned}
& =9.600 \text { L.E. } \quad(4) \\
& =\mathbf{1 3 . 8 2 4} \quad \text { L.E. }
\end{aligned}
$$

- Total Revenue from the project (5 basins):

The first basin

The four basins

\section{$\therefore$ Total Revenue at the first year}

$23824 * 357$ day a year

$$
\begin{aligned}
& =10.000 \text { L.E. } \\
& =\frac{13.792 \text { L.E. }}{\mathbf{2 3 . 8 2 4} \text { L.E. }}
\end{aligned}
$$

Nearly 8.500.000 L.E.

*357 days is calculated taking into considerations vacations at the whole year.

The project predict about the minimum revenue that can be reached, and it can be increased after training the staff during the first year and will be increased by $25 \%$ in the following years up to $50 \%$ increase.

\section{3- Costs:}

\section{3-1) Cost of the Land:}

- We need a land from a range of 8-10 acres to grow algae, and it is preferred to establish the project near universities so we use the laboratories and can take advantage of them and 
analyze the samples and take advice from specialists in these universities.

- Suppose that the project will be a B.O.T. project, The average cost of the meter of the land is 2000 , so the total cost of the land will equal

10 acres $* 2000=20.000$ L.E.

\section{3-2) Cost of Civil Constructions:}

The construction of five basins to grow algae as its area is 4200 mt.sq is 7.475.000 L.E.

\section{3-3) Cost of trusses:}

The project needs two trusses, the average total cost $=$ 700.000 L.E.

\section{3-4)Cost of the administrative building and the store:}

The project needs two building, $2 * 300 \mathrm{sq} * 1500$ L.E. $=$ 900.000 L.E.

3-5) Cost of the Mechanical and electrical equipment and factorv production of biofuels:

The cost of the Mechanical and electrical equipment and the factory of Biofuel will approximately equal 4.000.000 L.E.

Depreciation $20 \%=800000$ L.E.

\section{3-6) Cost of Labor:}

- The project needs a Manager, his salary $=5000$

- $1 * 5000$ L.E. $* 13$ months $=65.000$

- Two Technical supervisors $2 * 3000$ L.E. $* 13$ Months $=$ 78.000 L.E.

- Factory worker (Technical) $2000 * 12$ months 24.000 L.E.

- Five Technical workers $5 * 2500013$ months $=162.500$ L.E. 
- Workers: We need an average of ten labors, so

$10 * 2000 * 13=$

260.000L.E.

$\therefore$ Total Cost of labors at the first year $=$

565.500 L.E.

- 3-7) Cost of Fuel. electricity and transitions and guard $=500.000$ L.E.

Table (2) shows the total amount invested in Spirulina pilot farm, and table (3) shows the net cash flow of the project

Table (2)

Total amount invested in the project

\begin{tabular}{|l|c|c|}
\hline \multirow{2}{*}{ Items } & \multicolumn{2}{c|}{ First Year } \\
\cline { 2 - 3 } Investment Costs: & & Total \\
\hline Equipements & 4.000 .000 & \\
\hline Trusses & 700.000 & \\
\hline Building & 900.000 & \\
\hline Total Investment costs & & $\mathbf{5 . 6 0 0 . 0 0 0}$ \\
\hline The cost of civil works & & \\
\hline Brick buidings & 750.000 & \\
\hline Concretes & 4.725 .000 & \\
\hline Moisture proofing & 2.000 .000 & \\
\hline Total costs of civil works & & $\mathbf{7 . 4 7 5 . 0 0 0}$ \\
\hline Indirect Costs & & \\
\hline External supervision & 500.000 & \\
\hline Unforeseen expenses & 500.000 & \\
\hline Total Indirect costs & & $\mathbf{1 . 0 0 0 . 0 0 0}$ \\
\hline Indirect Costs & & \\
\hline B.O.T. of Land & & 20.000 \\
\hline Direct costs & & \\
\hline Total Labor & 565.500 & \\
\hline $\begin{array}{l}\text { Fuel, electricity and } \\
\text { transitions }\end{array}$ & 500.000 & \\
\hline Operating Cost & & 1.085 .500 \\
\hline Total Investment Cost & & $\mathbf{1 5 . 1 6 0 . 5 0 0}$ \\
\hline
\end{tabular}

*All numbers was calculated by the researcher 
Table (3)

Net Profit

\begin{tabular}{|l|c|c|c|c|c|}
\hline Item/Year & 1 & 2 & 3 & 4 & 5 \\
\hline Total Revenue & $\mathbf{8 . 5 0 0 . 0 0 0}$ & 10.625 .000 & 15.937 .500 & 23.906 .250 & 35.859 .375 \\
\hline $\begin{array}{r}\text { Deducting } \\
\text { Direct \& } \\
\text { Indirect costs }\end{array}$ & 2.085 .500 & 2.085 .500 & 2.085 .500 & 2.085 .500 & 2.085 .500 \\
\hline $\begin{array}{r}\text { Net profit } \\
\text { after } \\
\text { deducting } \\
\text { investment } \\
\text { costs }\end{array}$ & 6.414 .500 & 8.539 .500 & 13.852 .000 & 21.820 .750 & 33.773 .875 \\
\hline
\end{tabular}

*All numbers was calculated by the researcher

Table (4)

Net cash flow for the project

\begin{tabular}{|c|c|c|c|c|c|c|c|c|c|c|c|}
\hline Items/Years & -1 & 1 & 2 & 3 & 4 & 5 & 6 & 7 & 8 & 9 & 10 \\
\hline \multicolumn{12}{|l|}{ Cash inflow } \\
\hline Loan & 15.160 .500 & & & & & & & & & & \\
\hline Revenues & & 8.500 .000 & 8.500 .000 & 8.500 .000 & 8.500 .000 & 8.500 .000 & 8.500 .000 & 8.500 .000 & 8.500 .000 & 8.500 .000 & 8.500 .000 \\
\hline Total Inflow & 15.160 .500 & 8.500 .000 & 8.500 .000 & 8.500 .000 & 8.500 .000 & 8.500 .000 & 8.500 .000 & 8.500 .000 & 8.500 .000 & 8.500 .000 & 8.500 .000 \\
\hline \multicolumn{12}{|l|}{$\frac{\text { Cash }}{\text { Outflow }}$} \\
\hline $\begin{array}{c}\text { Investment } \\
\text { Cost }\end{array}$ & 15.160 .500 & & & & & & & & & & \\
\hline $\begin{array}{c}\text { Operating } \\
\text { Cost }\end{array}$ & - & 1.085 .500 & 1.085 .500 & 1.085 .500 & 1.085 .500 & 1.085 .500 & 1.085 .500 & 1.085 .500 & 1.085 .500 & 1.085 .500 & 1.085 .500 \\
\hline $\begin{array}{c}\text { Loan } \\
\text { Service }\end{array}$ & - & 3.500 .000 & 3.300 .000 & 3.080 .000 & 2.850 .000 & 2.630 .000 & 2.400 .000 & 2.180 .000 & 1.950 .000 & 1.730 .000 & 1.500 .000 \\
\hline Total inflow & 15.160 .500 & 4.585 .000 & 4.385 .500 & 4.165 .000 & 3.935 .500 & 3.715 .500 & 3.485 .500 & 3.265 .500 & 3.035 .500 & 2.815 .500 & 2.585 .500 \\
\hline $\begin{array}{l}\text { Net Cash } \\
\text { Flow }\end{array}$ & 0 & 3.915 .000 & 4.114.500 & 4.335 .000 & 4.546 .500 & 4.784 .500 & 5.014 .500 & 5.234 .500 & 5.464 .500 & 5.684 .500 & 5.914 .500 \\
\hline
\end{tabular}

*All numbers was calculated by the researcher 
From former Net cash flow table, we can conclude the table of the daily income of Spirulina algae resulted from the four basins as follow:

Table (5)

Daily Income of using 4 basins of algae (fuel/food/medicine) in $\$$

\begin{tabular}{|c|c|c|c|}
\hline Item & $\begin{array}{c}\text { Uses } \\
\text { (Products) }\end{array}$ & Revenues & Notes \\
\hline Fuel K.g. /Day & $\begin{array}{c}54 \text { K.g.*4 } \\
\text { basins }\end{array}$ & $216 * 1.5 \$$ & $\begin{array}{r}\text { With the beginning } \\
\text { of 2017 the price of } \\
\text { a kilogram has } \\
\text { increased to \$ 4 }\end{array}$ \\
\hline Glessrin K.g/day & $\begin{array}{c}\text { 616 K.g.* } \\
\text { basins }\end{array}$ & $\mathbf{3 2 4} \mathbf{\$}$ & \\
\hline Feed K.g/day & 160 K.g. & $160 * 7.5 \$$ & \\
\hline Daily Total Revenues & $\mathbf{1 6 0}$ K.g. & $\mathbf{1 2 0 0} \mathbf{\$}$ & \\
\hline
\end{tabular}

*All numbers was calculated by the researcher

\section{Sensitive Analysis:}

The test has being available to identify the project's ability to succeed in front of negative conditions, the study has developed three scenarios of those circumstances:

- An increase in the price of the dollar to 15 pounds instead of 8 pounds.

- An increase in the price of the dollar to 20 pounds

- An increase in the price of the dollar to 25 pounds 
The result of the analysis proved the ability of the project to success in the light of those three proposals, where the results were as follows:

Table (6)

Three Scenarios if the price of Dollar increase

\begin{tabular}{|r|r|r|r|}
\hline \multicolumn{1}{|c|}{ Item } & \multicolumn{1}{|c|}{$\mathbf{1 5} \mathbf{2 0} \$$} & \multicolumn{1}{c|}{$\mathbf{2 5} \mathbf{\$}$} \\
\hline Biofuel & $324 * 15=4860$ & $324 * 20=6480$ & $324 * 25=8100$ \\
\hline Glessrin & $204 * 15=3060$ & $204 * 20=4080$ & $204 * 25=5100$ \\
\hline Feed & $1200 * 15=18000$ & $1200 * 20=24000$ & $1200 * 25=30000$ \\
\hline
\end{tabular}

*All numbers was calculated by the researcher

Net profit

Total Investment Cost

\section{$\underline{6.414 .500}$}

$$
15.160 .500=
$$

$42.3 \%$

\section{Conclusions:}

- The research paper highlighted on the production of spirulina algae as a source of food and biofuels in the future as it is economically feasible and profitable

- Spirulina project contributes to the creation of jobs for many young people.

- The Spirulina Project will contribute to both the Economical and Social aspects, through the wide spread of using Spirulina algae as a food, medicine and biofuel; thereby it will contribute in supporting of sustainable development plans and will reduce the rates of poverty and hunger, as well as create millions of new jobs and increase the profitability of farmers and peasants. Fuel crops can increase their profitability by four or five times, and this will support many industries related to agriculture, including fertilizer and pesticides. 
- Table (3) shows that the net revenues at the first year after deducting investment costs reached 6.414.500 L.E.

- Table (4) shows that After deducting the value of the loan at the first year by an amount of 3,500,000 L.E. from the value of the net profit, the total net cash flow will reach an amount of 3,915,500 L.E., and this means that the total profit covers the total direct and indirect investment costs and the loan. When we train the employee to produce Spirulina algae by different advanced types of equipment, profit will increase by $25 \%$ after the first year and 50\% after the second year.

- From Table (3) To calculate profit after deducting the direct and indirect costs (investment costs), profit reached 8,539,500 L.E. at the second year of the project, and when repaying loan at the second year by an aount of 3,300,000 L.E. the net cash flow will be 4,114,500 L.E.

- The third year indicates that the total profit increases by $50 \%$ to record an amount of 21,820,750 L.E., and after deducting the repayment value of the Loan by an amount of $3,080,000$, the net cash flow will be 4,334,500 L.E.

At the tenth year at the end of the loan, we find that the net cash flow will reach an amount of 5,914,500 L.E. after repaying the loan and deducting operating costs. Therfore this means that project is a very profitable project, and the research paper concentrates on producing Spirulina algae as it is economically feasible and profitable.

\section{Recommendations:}

1. All countries especially Egypt should seek to solve the biofuel problem through the expansion of producing Spirulina Algae, especially in deserts, where there are hundreds of millions of acres of land and adequate water resources. 
2. Expansions in the production of Spirulina in the desert regions as these species do not need large amounts of water, but they can grow on rain water only.

3. The Need to support businessmen and investors in order to expand the production of Spirulina Algae by using a greater propaganda and announcing the advantages of using Spirulina Algae to familiarize the public with its medical high value and as a source of Biofuel. 


\section{References:}

- A. Milbrandt, C. Kinchin (2013), the Feasibility of Producing and Using Biomass-Based Diesel and Jet Fuel in the United States, NREL/TP-6A20-58015.

- Anitha Layam, Chandra Lekha Kasi Reddy (2007), ANTIDIABETIC PROPERTY OF SPIRULINA, Department of Food Science and Nutrition, SPMVV, Tirupati, India.

- Bob Capelli, Gerald r. Cysewski (2010), Potential health benefits of Spirulina microalgae: A review of the existing literature, Research Nutrafoods, Volume9, Issue 2, pp 19-26 available online at www.ceceditore.com

- Ernest Small (2012): 37. Spirulina: food for the universe, Biodiversity, available online at http://dx.doi.org/10.1080/14888386.2011.642735

- FAO (2008), Fisheries and Aquaculture Circular No. 1034, a review on culture, production and use of Spirulina as food for humans and feeds for domestic animals and Fish, Rome, available online at www.enace.org/.../2013/aquaculture-asiaapril-june-2013-web.pdf

- Giuliano Dragone, Bruno Fernandes (2010) Third generation biofuels from microalgae, http://www.formatex.info/microbiology2/1355-1366.pdf

- Kifayat Ullah and others (2014), Algal biomass as a global source of transport fuels: Overview and development perspectives, Elsevier, (2014)329-339.

- Md. Nahian Bin Hossain (2014), the production of Ethanol from Micro-Algae Spirulina, retrieved from

www.sciencedirect.com

- Michale Hannon, Javier Gimpel, Miller Tran, Beth Rasala, Stephen Mayfield (2010), Biofuels from algae: challenges and potential, NIH, Biofuels, 1(5):763-784. retrieved from

http://www.ncbi.nlm.nih.gov/pmc/articles/PMC3152439/

- Mostafa, S.S.M., el-Gendy, N.S. (2013), Evaluation of fuel properities for microalgae Spirulina platensis bio-diesel and its belnds with Egyptian petro-diesel Spirulina platensis biodiesel, Arabian Journal of Chemistry. 
- Pokoo-Aikins, Grace, Ahmed Nadim, Mahmoud M. ElHalwagi, and Vladimir Mahalec (2010), "Design and analysis of biodiesel production from algae grown through carbon sequestration. "Clean Technologies and Environmental Policy.

- Raphael Slade, Ausilio Bauen, (2013) Micro-algae cultivation for biofuels: cost,energy balance, environmental impacts and future prospects, Elsevier Ltd.

- Ravindra Singh, Pushpendra Singh, Arpana Mishra (2014), Algae-An alternative source of biofuel. 3rd World Conference on Applied Science, Engineering and Technology 27-29 September 2014, Kathmandu,Nepal, ISBN 13:978-81-930222-0-7.

- R.Sayre (2013), Algal Biology and Cultivation: Technical Accomplishments, Progress and

- Sayre, R., (2013) Algal biology and cultivation. Technical Accomplishments, Progress and Results. Presentation at 2013 Bioenergy Technologies Office Peer Review, Alexandria, VA, May 2013. retrieved from

https:www2.eere.energy.gove/biomass/peer_review2013/Porta $1 / \mathrm{IBR} / \#$.

- Shakhashiri, chemicals of the week (2009) www.scifun.org

- Sheehan, J.; Dunahay, T.; Benemann, J.; Roessler, P. A (1998) Look Back at the U S Department of Energy's Auatic Species Program - Biodiesel from Algae. Vol. 328. National Renewable Energy Laboratory; Co, USA.

- T.J. Lundquist, L.C. Woertz, (October 2010), A Realistic Technology and Engineering Assessment of Algae biofuel Production, energy Biosciences Institute University of California, Berkeley, California.

- Xiaodong Deng, Yajun Li, and Xiaowen Fei (2009), Microalgae: A promising feedstock for biodiesel, African Journal of Microbiology Research Vol. 3(13) pp. 1008-1014, ISSN 1996-0808@2009 Academic Journals. 